Marquette University

e-Publications@Marquette

Biological Sciences Faculty Research and

Publications

Biological Sciences, Department of

2-2012

\title{
Ornithine Decarboxylase mRNA is Stabilized in an mTORC1-dependent Manner in Ras-transformed Cells
}

\author{
Sofia Origanti \\ Marquette University, sofia.origanti@marquette.edu \\ Shannon L. Nowotarski \\ Penn State College of Medicine \\ Theresa D. Carr \\ Penn State College of Medicine \\ Suzanne Sass-Kuhn \\ Penn State College of Medicine \\ Lan Xiao \\ University of Maryland - Baltimore
}

See next page for additional authors

Follow this and additional works at: https://epublications.marquette.edu/bio_fac

Part of the Biology Commons

\section{Recommended Citation}

Origanti, Sofia; Nowotarski, Shannon L.; Carr, Theresa D.; Sass-Kuhn, Suzanne; Xiao, Lan; Wang, Jian-Ying; and Shantz, Lisa M., "Ornithine Decarboxylase mRNA is Stabilized in an mTORC1-dependent Manner in Ras-transformed Cells" (2012). Biological Sciences Faculty Research and Publications. 432.

https://epublications.marquette.edu/bio_fac/432 


\section{Authors}

Sofia Origanti, Shannon L. Nowotarski, Theresa D. Carr, Suzanne Sass-Kuhn, Lan Xiao, Jian-Ying Wang, and Lisa M. Shantz

This article is available at e-Publications@Marquette: https://epublications.marquette.edu/bio_fac/432 


\title{
Ornithine decarboxylase mRNA is stabilized in an mTORC1- dependent manner in Ras-transformed cells
}

\author{
Sofia Origanti ${ }^{1}$ \\ Department of Cellular and Molecular Physiology, \\ Penn State College of Medicine \\ Hershey, PA \\ Shannon L. Nowotarski² \\ Department of Cellular and Molecular Physiology, \\ Penn State College of Medicine \\ Hershey, $P A$
}

Corresponding author: Lisa M. Shantz, Ph.D., Associate Professor, Department of Cellular and Molecular Physiology H166, Room C4731, The Penn State College of Medicine, 500 University Drive, Hershey, PA 17033, USA, phone: 717-531-1562, fax: 717-531-7667, Ims17@psu.edu.

${ }^{1}$ Current address: Sofia Origanti, Ph.D., Department of Cell Biology and Physiology, Washington University School of Medicine,

St. Louis, MO 63110, USA

${ }^{2}$ Current address: Shannon L. Nowotarski, Ph.D., The Sidney Kimmel Comprehensive Cancer Center, The Johns Hopkins

University School of Medicine, Baltimore, MD 21231, USA

AUTHOR CONTRIBUTIONS: Sofia Origanti performed the majority of the experiments and was involved in writing and editing the manuscript. Shannon Nowotarski, Theresa Carr, Suzanne SassKuhn and Lian Xiao performed some of the experiments. Jian-Ying Wang provided reagents and critical reading of the manuscript. Lisa Shantz had the original idea, secured funding, and was involved in writing and editing the manuscript.

Biochemical Journal, Vol 442, No. 1 (February 2012): pg. 199-207. DOI. This article is (C Portland Press Limited and permission has been granted for this version to appear in e-Publications@Marquette. Portland Press Limited does not grant permission for this article to be further copied/distributed or hosted elsewhere without the express permission from Portland Press Limited. 


\title{
Theresa D. Carr
}

Department of Cellular and Molecular Physiology,

Penn State College of Medicine

Hershey, $P A$

\author{
Suzanne Sass-Kuhn \\ Department of Cellular and Molecular Physiology, \\ Penn State College of Medicine \\ Hershey, $P A$ \\ Lan Xiao \\ Department of Surgery, \\ University of Maryland School of Medicine \\ Baltimore, MD \\ Department of Pathology, \\ University of Maryland School of Medicine \\ Baltimore, MD

\section{Jian-Ying Wang} \\ Department of Surgery, \\ University of Maryland School of Medicine \\ Baltimore, MD \\ Department of Pathology, \\ University of Maryland School of Medicine \\ Baltimore, MD \\ Baltimore Veterans Affairs Medical Center \\ Baltimore, $M D$
}

\author{
Lisa M. Shantz \\ Department of Cellular and Molecular Physiology, \\ Penn State College of Medicine \\ Hershey, PA
}

Biochemical Journal, Vol 442, No. 1 (February 2012): pg. 199-207. DOI. This article is @ Portland Press Limited and permission has been granted for this version to appear in e-Publications@ Marquette. Portland Press Limited does not grant permission for this article to be further copied/distributed or hosted elsewhere without the express permission from Portland Press Limited. 
NOT THE PUBLISHED VERSION; this is the author's final, peer-reviewed manuscript. The published version may be accessed by following the link in the citation at the bottom of the page.

\section{Abstract:}

Upon ras activation, ornithine decarboxylase (ODC) is markedly induced, and numerous studies suggest that ODC expression is controlled by Ras effector pathways. ODC is therefore a potential target in the treatment and prevention of Ras-driven tumors. We compared ODC mRNA translation profiles and stability in normal and Ras12V-transformed rat intestinal epithelial (RIE-1) cells. While translation initiation of ODC increased modestly in Ras $12 \mathrm{~V}$ cells, ODC RNA was stabilized 8-fold. Treatment with the specific mTORC1 inhibitor rapamycin or siRNA knockdown of mTOR destabilized the ODC message, but rapamycin had only a minor effect on ODC translation initiation. Inhibition of mTORC1 also reduced the association of the mRNA binding protein HuR with the ODC transcript. We have shown previously that HuR binding to the ODC $3^{\prime}$ UTR results in significant stabilization of the ODC mRNA, which contains several AU- rich regions within its 3'UTR that may act as regulatory sequences. Analysis of ODC 3'UTR deletion constructs suggests that cis-acting elements between bases 1969 and 2141 of the ODC mRNA act to stabilize the ODC transcript. These experiments thus define a novel mechanism of ODC synthesis control. Regulation of ODC mRNA decay could be an important means of limiting polyamine accumulation and subsequent tumor development.

Keywords: ornithine decarboxylase, mRNA stability, translation initiation, mTOR, rapamycin, HuR

\section{INTRODUCTION}

Increased activity of ornithine decarboxylase (ODC), the first biosynthetic enzyme of the polyamine pathway, has been demonstrated in a variety of human malignancies, including prostate cancer, squamous cell carcinoma of the skin and colon cancer (reviewed in [1]). Intracellular levels of ODC are tightly regulated, and multiple means of ODC dysregulation can occur in response to oncogenic stimuli. We have used in vitro and in vivo models of Ras activation to establish that ODC activity is regulated by and necessary for Ras-dependent cellular transformation, as well as transformation brought about by the Ras effectors MEK and eIF4E [2-5]. Activation of ODC transcription and protein synthesis is dependent on pathways downstream of Raf/MEK/ERK and PI3K/mTOR in both fibroblast and epithelial models $[3,6]$. The cooperation of pathways controlled by Raf and PI3K/mTOR is necessary for complete Ras transformation of several types of epithelial cells (reviewed in [7]). Since most solid

Biochemical Journal, Vol 442, No. 1 (February 2012): pg. 199-207. DOI. This article is (C Portland Press Limited and permission has been granted for this version to appear in e-Publications@Marquette. Portland Press Limited does not grant permission for this article to be further copied/distributed or hosted elsewhere without the express permission from Portland Press Limited. 
tumors are epithelial in origin, understanding how ODC synthesis is controlled by these pathways is crucial in defining the role of ODC in maintaining a transformed phenotype.

Cap-dependent translational regulation of ODC through its 5'untranslated region (5'UTR) is well-established, and ODC activity and translation are induced in eIF4E-overexpressing fibroblasts (4E-P2 cells) $[2,8]$. However, our studies in rat intestinal epithelial cells (RIE1 cells) described here suggest an alternate post-transcriptional regulatory mechanism for ODC protein synthesis. In this system, ODC synthesis is regulated primarily by changes in the levels of ODC RNA associated with polysomes, rather than changes in translation initiation. The mechanism of this regulation is a marked stabilization of the ODC mRNA in Ras12V-transformed RIE-1 cells (Ras12V cells) compared to their nontransformed parental controls, which appears to be regulated at least in part by pathways downstream of mTOR Complex 1 (mTORC1). Although the primary function of mTORC1 is in controlling the availability of eIF4E for translation initiation (reviewed in [9]), several studies show that TOR inhibition results in RNA stabilization. In $S$. Cerevisiae inhibition of TORC1 using the specific inhibitor rapamycin induced destabilization of multiple mRNAs, suggesting that TORC1 functions also involve regulation of mRNA turnover $[10,11]$. In mammalian systems, rapamycin treatment of mouse embryo fibroblasts increased the degradation of mRNAs corresponding to Cyclin D1 and c-Myc in an Akt-dependent manner [12], while treatment of breast cancer MDA-MB-231 cells with rapamycin resulted in destabilization of IL-8 mRNA [13].

Regulation of mRNA stability is recognized to play a pivotal role in controlling gene expression. Sequences defined as adenylate- and uridylate-rich elements (AREs), which are classified based on the number and context of the sequence $5^{\prime}$-AUUUA-3', are present within the 3'UTRs of many proto-oncogene, transcription factor and cytokine mRNAs (reviewed in $[14,15]$ ), and can act as determinants of mRNA stability. The mouse, rat and human ODC 3'UTR sequences, each of which is between $600-700$ bases in length, have several potential AREs within approximately 300 bases the stop codon. A number of regulatory proteins are known to interact with ARE sequences. These proteins not only control transcript decay, but can also influence translational efficiency, or cause the bound RNA transcript to move to

Biochemical Journal, Vol 442, No. 1 (February 2012): pg. 199-207. DOI. This article is (C Portland Press Limited and permission has been granted for this version to appear in e-Publications@Marquette. Portland Press Limited does not grant permission for this article to be further copied/distributed or hosted elsewhere without the express permission from Portland Press Limited. 
a processing body (P-body) for storage [16]. We have shown recently that the ubiquitous member of the ELAV protein family HuR associates with ODC mRNA in transformed cells and causes the ODC transcript to be stabilized [17]. Our results described here suggest that changes in ODC mRNA stability are mediated by cis-acting elements within the ODC 3'UTR and pathways downstream of MTORC1 play a role in this regulation at least in part by controlling the association of HuR with the ODC transcript.

\section{EXPERIMENTAL}

\section{Cell culture and inhibitors}

RIE-1 cells (a kind gift of Dr. Kenneth Brown, University of Cambridge, UK) were maintained in Dulbecco's modified Eagle's medium (DMEM) supplemented with $10 \%(\mathrm{v} / \mathrm{v})$ fetal bovine serum (FBS) and $100 \mu \mathrm{g} / \mathrm{ml}$ penicillin and streptomycin. Ras12V cells were generated from RIE-1 cells as described previously [6]. Sources for inhibitors were as follows: PD98059 was purchased from EMB4Biosceinces (Rockland, MA). CGP57380 was purchased from Tocris Bioscience (Ellisville, MO). Rapamycin was obtained from the Developmental Therapeutics Program of the National Cancer Institute.

\section{Western blot analysis}

Cells were plated and treated with inhibitors in DMSO as described in the figure legends, then extracted in RIPA buffer (EMB4Bioscience). Total cellular protein $(20 \mu \mathrm{g})$ was used for analysis. Membranes were probed using a purified rabbit polyclonal antibody raised against a 6Xhis-Tagged ODC protein as described previously [3], or a mouse monoclonal antibody against HuR (Santa Cruz Biotech, Santa Cruz, CA). Other antibodies used were as follows: GAPDH, 4EBP1, S6K1 and ERK1/2 polyclonal antibodies (Cell Signaling Technology, Danvers, MA); Actin and Lamin B polyclonal antibodies (Santa Cruz Biotech). To prepare cytoplasmic and nuclear extracts, cells were fractionated using the Pierce Fractionation Kit as per the manufacturer's instructions (Pierce, Rockford, IL).

\section{Generation of pGL3-ODC3'UTR constructs}

The full-length construct was made by PCR amplification of the 735 base ODC 3'UTR from Ras12V cells and ligation into the pGL3-

Biochemical Journal, Vol 442, No. 1 (February 2012): pg. 199-207. DOI. This article is @ Portland Press Limited and permission has been granted for this version to appear in e-Publications@Marquette. Portland Press Limited does not grant permission for this article to be further copied/distributed or hosted elsewhere without the express permission from Portland Press Limited. 
control expression vector (Promega, Madison, WI). Orientation of the 3'UTR was confirmed by sequencing. Deletion mutants of the ODC 3'UTR were constructed by PCR using the same template and antisense primers designed to produce deletions from the distal end of the 3'UTR.

\section{Immunoprecipitation analysis of translation initiation factors and Methyl-7-GTP sepharose chromatography}

Ras $12 \mathrm{~V}$ cells $\left(7 \times 10^{5}\right.$ cells/plate $)$ and RIE- 1 cells $\left(9 \times 10^{5}\right.$ cells/plate) were plated on $10 \mathrm{~cm}$ plates, allowed to adhere overnight and extracted $24 \mathrm{~h}$ later. For inhibitor treatments Ras $12 \mathrm{~V}$ cells were treated for $2 \mathrm{~h}$ with either DMSO or $100 \mathrm{nM}$ rapamycin after $24 \mathrm{~h}$ of growth. Cell extracts were prepared as described previously [18].

\section{Polysome analysis}

Polysome analysis was carried out as described previously [19] using $9 \times 10^{5}$ RIE- 1 or $7 \times 10^{5}$ Ras $12 \mathrm{~V}$ cells per $10 \mathrm{~cm}$ plate. Analysis was performed after $24 \mathrm{~h}$ of growth. Sucrose gradients (20-47\%) were centrifuged at $34000 \mathrm{rpm}$ for $5 \mathrm{~h}$ using a SW41 rotor (Beckman Coulter, Brea, CA). Absorbance was followed at $254 \mathrm{~nm}$. A total of 11 fractions were collected every $30 \mathrm{sec}$. For each fraction equal volumes of RNA were analyzed by Northern blot hybridization. Integrity of RNA was ensured by staining formaldehyde agarose gels with Ethidium bromide.

\section{Synthesis of radiolabeled CDNA probes}

cDNA probes were prepared by radiolabeling 100ng DNA with [32-P]-dCTP using the Rad prime DNA kit (Invitrogen, Carlsbad, CA) according to the manufacturer's instructions. A full-length ODC probe was prepared from pGEM-ODC [3]. To prepare probes complementary to eEF1A and Cyclophilin, RNA from Ras12V cells was reverse transcribed and amplified by PCR.

\section{RNA stability assay}

Cells were cultured on $10 \mathrm{~cm}$ plates similar to polysome analysis. After $24 \mathrm{~h}$ of growth cells were treated with $5 \mu \mathrm{g} / \mathrm{ml}$ Actinomycin D (Sigma-Aldrich, St. Louis, MO) and RNA was isolated at defined time points using the RNAqueous kit (Ambion, Austin, TX).

Biochemical Journal, Vol 442, No. 1 (February 2012): pg. 199-207. DOI. This article is (C Portland Press Limited and permission has been granted for this version to appear in e-Publications@Marquette. Portland Press Limited does not grant permission for this article to be further copied/distributed or hosted elsewhere without the express permission from Portland Press Limited. 
Northern analysis was carried out using $20 \mu \mathrm{g}$ total RNA and radiolabeled cDNA probes synthesized for ODC and Cyclophilin as described above. Half-life of ODC RNA was determined by curve fit analysis. For Ras12V cells an approximate half-life was determined by extrapolation. Stability of pGL3-ODC3'UTR and mutant transcripts were compared by Northern blot analysis using a [32-P]-labelled firefly luciferase probe following transfection into RIE-1 and Ras $12 \mathrm{~V}$ cells.

\section{SiRNA experiments}

Previously validated rat mTOR siRNA and scrambled control oligonucleotides [20] were synthesized, annealed in vitro and transfected using oligofectamine (Invitrogen) at $80 \mathrm{nM}$ final concentration into Ras $12 \mathrm{~V}$ cells. At $48 \mathrm{~h}$ after transfection, Actinomycin D was added to the cells and stability of the ODC RNA was measured as described above. Extent of mTORC1 knockdown was assessed by measuring levels of hyperphosphorylated 4EBP1 by Western blot.

\section{Biotin-labeled RNA protein-binding assays}

A synthetic ODC transcript was generated by isolating total RNA from Ras12V cells, then using reverse transcriptase to produce cDNA. The cDNA was used as a template for PCR amplification of the full length $3^{\prime}$ UTR of ODC. The 5' primer sequence began with the T7 RNA polymerase promoter sequence (T7):

CCAAGCTTCTAATACGACTCACTATAGGGAGA to allow further amplification. The ODC 3'UTR was amplified and PCR products were purified and used as templates to transcribe biotinylated RNA using T7 RNA polymerase in the presence of biotinylated CTP [21]. The GAPDH 3'UTR was amplified in the same manner for use as a negative control. The resulting biotinylated products were used in RNA pull-down assays essentially as described [22]. Western blot analysis was used to examine the association of HuR with the pull-down materials. For analysis of HuR binding to the DEL02 truncation mutant, biotinylated probes were synthesized and analyzed as described previously [17]. Mutation of the AUUUA sequence to GGGUA was by site-directed mutagenesis using the Quikchange Mutagenesis Kit as per the manufacturer's instructions (Stratagene, La Jolla, CA). 


\section{Ribonucleoprotein immunoprecipitation (RNP IP)}

For immunoprecipitation of endogenous RNA-protein binding complexes, $2000 \mu \mathrm{g}$ of cytoplasmic lysate was incubated for $2 \mathrm{~h}$ at room temperature with $50 \%(\mathrm{v} / \mathrm{v})$ suspension of Protein A-Sepharose beads (Sigma-Aldrich) that had been pre-coated with $30 \mu \mathrm{g}$ of either mouse IgG (Invitrogen) or HuR antibodies as described [23]. The immunoprecipitated material was analyzed by washing the beads with NT-2 buffer (50 mM Tris- $\mathrm{HCl}$ (pH 7.4), $150 \mathrm{mM} \mathrm{NaCl}, 1 \mathrm{mM} \mathrm{MgCl}$, and $0.05 \%$ Nonidet P-40), and further incubated with $0.5 \mathrm{mg} / \mathrm{ml}$ Proteinase $\mathrm{K}, \mathrm{NT}-2$ buffer, and $0.1 \%$ SDS for $15 \mathrm{~min}$ at $55^{\circ} \mathrm{C}$. RNA was precipitated using phenol-chloroform extraction in the presence of glycoblue (Qiagen, Valencia, CA). RNA from the immumoprecipitation was then reverse transcribed to detect the presence of ODC mRNA.

\section{RESULTS}

\section{Stabilization of ODC MRNA upon Ras transformation of RIE-1 cells}

RIE-1 cells and their Ras-transformed counterparts are a valuable model in which to study the regulation of cellular polyamines $[22,24,25]$, The studies described here use RIE-1 cells stably expressing a constitutively active Ras12V mutant (Ras12V cells), which results in about a 25-fold induction in ODC activity, and empty vector parental controls [6]. To determine whether the increase in ODC activity observed could be explained by changes in ODC translation efficiency in response to Ras activation, polysome profiles were performed (Figure $1 \mathrm{~A}$ ). In addition to a slight shift in ODC RNA from lighter to heavier polysome fractions in Ras $12 \mathrm{~V}$ cells, which one would expect with increased translation initiation, we observed an increase in the amount of total polysome-associated RNA in the Ras12V cells in comparison to the control RIE-1 cells (Figure 1A). By normalizing the amount of ODC RNA in each fraction to the relatively constant levels of Cyclophilin RNA associated with polysomes in both Ras12V and RIE-1 cells, we observed a 5-fold increase in the amount of ODC RNA associated with the polysomal fractions in the Ras $12 \mathrm{~V}$ cells (Figure 1A).

The increase in ODC RNA associated with polysomes may result from increased interaction with stabilizing RNA binding proteins (RBPs)

Biochemical Journal, Vol 442, No. 1 (February 2012): pg. 199-207. DOI. This article is (C Portland Press Limited and permission has been granted for this version to appear in e-Publications@Marquette. Portland Press Limited does not grant permission for this article to be further copied/distributed or hosted elsewhere without the express permission from Portland Press Limited. 
or changes in its interaction with microRNAs (miRNAs). We have recently shown that the ODC transcript is stabilized by the RBP HuR in cells derived from skin carcinomas [17]. To determine whether changes in rate of mRNA decay could contribute to the dramatic ODC activity induction seen in Ras12V cells, we examined ODC RNA stability in both cell lines after exposure to Actinomycin D. The t1/2 for RIE-1 ODC RNA was $3.0 \mathrm{~h}$ (Figure $1 \mathrm{~B}, \mathrm{C}$ ), while the $\mathrm{t} 1 / 2$ in Ras $12 \mathrm{~V}$ cells was calculated to be $23.7 \mathrm{~h}$, indicating an 8 -fold increase in stability (Figure 1B, 1C). Cyclophilin served as a control.

\section{Inhibition of mTORC1 results in modest changes in ODC translation efficiency and a marked increase in ODC mRNA decay}

We have shown that post-transcriptional regulation of ODC is dependent on mTORC1- controlled pathways in several experimental systems $[3,6]$. Therefore, we were interested to determine whether treatment with rapamycin affected cap-dependent translation initiation of ODC in Ras12V cells. Treatment of Ras $12 \mathrm{~V}$ cells with rapamycin reduced ODC protein in a time-dependent manner to about $15 \%$ of protein levels found in untreated cells by $24 \mathrm{~h}$ (Figure $2 \mathrm{~A}$ ). This is in agreement with previous results showing inhibition of ODC enzyme activity by rapamycin in the same time frame [6].

Treatment with rapamycin for $2 \mathrm{~h}$ had only a modest effect on ODC translation efficiency (Figure 2B, 2C). On the other hand, the same treatment time inhibited translation of eEF1a by causing a shift in EF1a RNA from polysomal fractions to non-polysomal fractions (Figure 2B, 2C), confirming that rapamycin inhibited translation initiation of known targets in this time frame. Rapamycin treatment also increased the association of 4EBP1 with eIF4E as assayed by both IP analysis of eIF4E and by m7GTP sepahrose chromatography (Supplemental Figure 1). IP analysis revealed a decrease in the association of eIF4G with eIF4E as well (Supplemental Figure 1). These results together suggest that mTORC1 controls cap complex formation in Ras12V cells. Exposure of cells to rapamycin for $24 \mathrm{~h}$ also produced little change in ODC translation efficiency (Figure 2B, 2C), although this prolonged treatment caused both a dramatic decrease in ODC protein levels (Figure 2A) and an overall decrease in the levels of 40S, $60 \mathrm{~S}$, and $80 \mathrm{~S}$ ribosomal subunits (Figure 2B, 2C). 
To determine whether mTOR-dependent pathways may be involved in ODC mRNA stability control, we examined the effect of rapamycin on ODC mRNA decay in Ras $12 \mathrm{~V}$ cells. Since treatment with rapamycin for either $2 \mathrm{~h}$ or $24 \mathrm{~h}$ had similar effects on ODC polysome profiles (Figure 2), we decided to mimic the constitutive downregulation of mTOR-dependent signaling previously observed in RIE-1 cells [6] by treating the Ras12V cells with rapamycin for $24 \mathrm{~h}$. In vehicle-treated cells, the ODC RNA was very stable, with a calculated half-life of over $15 \mathrm{~h}$. In cells pre-treated with rapamycin (100 nM) the $\mathrm{t}_{1 / 2}$ was calculated to be about $6 \mathrm{~h}$ (Figure 3A, 3B). Rapamycin treatment does not change the half- life of ODC mRNA in RIE-1 cells (data not shown), consistent with the already low mTOR activity in these cells [6].

To investigate the contribution of other Ras-effector pathways to control of ODC mRNA decay, we used inhibitors of MEK (PD98059, 50 $\mu \mathrm{M})$ or the eIF4E kinase Mnk1 (CGP57380, $20 \mu \mathrm{M})$. We have shown previously that both MEK and Mnk1 contribute to ODC synthesis in Ras12V cells by enhancing internal ribosome entry site (IRES)mediated translation [6], and MEK-dependent pathways control ODC transcription [3]. However, the results shown in Figure $3 \mathrm{~A}$ and $3 \mathrm{~B}$ suggest that neither pathway appears to play a major role in controlling ODC mRNA stability. To confirm the specificity of each inhibitor for its target, we measured activation of both MTORC1 and MEK signaling. Treatment with rapamycin completely inhibited phosphorylation of S6K1 and reduced hyperphosphorylation of 4EBP1, indicating inhibition of mTORC1-dependent pathways (Figure 3C). Activation of ERK is also seen in rapamycin-treated cells, consistent with previous results showing up-regulation of the MEK-ERK signaling cascade upon S6K1 inhibition [26]. On the other hand, inhibition of MEK with PD98059, while abolishing ERK phosphorylation, had no effect on mTORC1 activity (Figure 3C). Although ERK can phosphorylate and inhibit TSC2, leading to activation of MTOR, we have shown previously that the levels of activated Akt in Ras12V cells are very high [6]. These results suggest that TSC2 is phosphorylated primarily by Akt in these cells. CGP57380, which we previously showed to be a very effective inhibitor of Mnk1 in Ras12V cells [6], had no effect on either mTORC1 or ERK signaling cascades (Figure 3C). 


\section{mTOR knockdown mimics the effect of rapamycin treatment on ODC mRNA decay}

To confirm the effect of rapamycin on the destabilization of ODC mRNA, we knocked down mTOR using an siRNA approach. Reduction in mTOR by siRNA results in inhibition of both mTORC1- and mTORC2dependent pathways, while mTORC2 is not sensitive to rapamycin in most (though not all) models of tumorigenesis [27, 28]. We estimated the extent of mTOR knockdown $48 \mathrm{~h}$ after transfection by measuring the levels of both total and phosphorylated 4EBP1. When compared to 4EBP1 levels in parental RIE-1 cells, both total 4EBP1 and its hyperphosphorylated gamma form were clearly increased in Ras12V cells transfected with a scrambled siRNA, consistent with increased mTOR activity and protein synthesis in Ras $12 \mathrm{~V}$ cells compared to RIE-1 cells [6]. In contrast, hyperphosphorylated 4EBP1 was largely eliminated in Ras12V cells transfected with the mTOR siRNA (Figure $4 A$ ). This result suggests that mTORC1 activity is effectively inhibited in the mTOR siRNA-transfected cells.

To determine ODC message stability in the presence of mTOR knockdown, Actinomycin D was added and Northern analysis was performed using Ras $12 \mathrm{~V}$ cells transfected with either scrambled siRNA or mTOR siRNA. These results show that knockdown of mTOR destabilizes the ODC transcript compared to a scrambled siRNA that does not knock down mTOR (Figure 4B). Quantitation of the mRNA showed about a $15 \mathrm{~h}$ half-life in cells treated with a scrambled siRNA, and $\mathrm{a} 7 \mathrm{~h}$ half-life in cells exposed to an siRNA directed to mTOR (Figure 4C). These results are very similar to those obtained with rapamycin treatment (Figure 3 ) and confirm that pathways dependent on mTORC1 regulate the decay of the ODC mRNA in Ras12V cells.

\section{Endogenous HuR associates with the ODC 3'UTR in Ras12V cells in a rapamycin-dependent manner}

We have shown previously using keratinocyte-derived cell lines that the RBP HuR associates with the ODC 3'UTR and stabilizes the ODC message in carcinoma cells but not in non-transformed cells [17]. To confirm that those results are not limited to the skin, we first performed an experiment designed to determine the intracellular localization of HuR in unstimulated parental and Ras12V-transformed

Biochemical Journal, Vol 442, No. 1 (February 2012): pg. 199-207. DOI. This article is (C Portland Press Limited and permission has been granted for this version to appear in e-Publications@Marquette. Portland Press Limited does not grant permission for this article to be further copied/distributed or hosted elsewhere without the express permission from Portland Press Limited. 
RIE-1 cells (Figure 5A). While HuR was predominantly nuclear in both cell lines, there was significant accumulation of HuR in the cytoplasm as well. Quantitation of bands revealed about a 2-fold increase in cytoplasmic HuR in Ras12V cells compared to their non-transformed counterparts (Figure 5A, 5B).

These results differ from those reported previously in keratinocyte-derived cells, where HuR was exclusively nuclear in normal keratinocytes, but present in both the nucleus and cytoplasm of carcinoma cells [17].

We assessed the intracellular association of ODC mRNA with HuR in parental RIE-1 cells and their Ras-transformed counterparts using RNP IP assays, which allow the association between HuR and its target mRNAs to be maintained. Interestingly, almost no ODC mRNA was bound to HuR in lysates from RIE-1 cells, in spite of the presence of HuR in the cytoplasm. On the other hand, a strong association between HuR and ODC was observed in Ras12V cells (Figure 5B), similar to our results in skin carcinoma cells [17]. The lack of association in RIE- 1 cells was not due to the absence of ODC mRNA from RIE-1 lysates. Indeed, ODC message is clearly present in both cell lines (Figure 5B).

Ras12V cells were next treated with 100 nM rapamycin for $1 \mathrm{~h}$, $8 \mathrm{~h}$, or $24 \mathrm{~h}$, then harvested and analyzed as described above. This concentration of rapamycin blocks phosphorylation of both of the mTORC1 targets 4EBP1 and S6-kinase in Ras12V cells ([6] and Figure 3 ). We observed a time-dependent decrease in the amount of ODC message present in the HuR immunoprecipitate in the presence of rapamycin (Figure $5 \mathrm{C}$ ), suggesting that HuR interaction with the ODC mRNA is mediated in an mTORC1-dependent manner. Further, the time course of reduction in HuR association with the ODC message corresponds to the change in ODC activity in rapamycin-treated cells shown in Figure 1. There was no measurable change in either total HuR or the ratio of nuclear to cytoplasmic HuR in Ras12V cells, even after $24 \mathrm{~h}$ exposure to rapamycin (Figure 5D). This is consistent with the observation that RIE-1 cells also contain HuR in both the nucleus and cytoplasm (Figure 5A), in spite of very low levels of mTOR activity.

Biochemical Journal, Vol 442, No. 1 (February 2012): pg. 199-207. DOI. This article is (C Portland Press Limited and permission has been granted for this version to appear in e-Publications@Marquette. Portland Press Limited does not grant permission for this article to be further copied/distributed or hosted elsewhere without the express permission from Portland Press Limited. 
NOT THE PUBLISHED VERSION; this is the author's final, peer-reviewed manuscript. The published version may be accessed by following the link in the citation at the bottom of the page.

\section{Identification of cis-acting stability elements in the ODC 3'UTR}

The regulation of mRNA decay involves interaction of transacting factors with cis-acting sequences that confer stability to a transcript. Many cis-acting sequences contain AREs within them, and the ODC 3'UTRs from mouse, rat and human contain several sequences that would be identified as AREs within the first 300 bases after the termination codon (Supplemental Figure 2). Our previous results suggest that elements within this ODC 3'UTR proximal end are responsible for stabilizing the ODC message by interacting with HuR [17].

In order to identify cis-acting elements within the ODC 3'UTR, we constructed several expression vectors in which the firefly luciferase open reading frame is linked to the full length mouse ODC

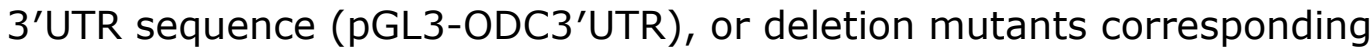
to those used previously for HuR binding studies [17]. Stability of pGL3- ODC3'UTR and deletion transcripts was compared following transfection. The half-life of RNA derived from a luciferase reporter construct containing the full-length ODC 3'UTR (725 bases) was approximately $22 \mathrm{~h}$ in Ras $12 \mathrm{~V}$ cells but only $7.5 \mathrm{~h}$ in RIE-1 cells (Figure $6 \mathrm{~A})$. This is in good agreement with the half-life of the endogenous ODC transcript (Figure 1B). Deletions in the 3'UTR from the distal end showed that deleting the last 381 bases to create a 344 base long 3'UTR (DEL01) had no effect on mRNA decay in Ras12V cells (Figure 6A). However, when an additional 172 bases were deleted (DEL02, 172 bases long), the ODC mRNA t1/2 decreased about 3-fold, and was not changed substantially by further deletion to create a 53 base long 3'UTR (DEL03). Steady state mRNA levels of transcripts derived from all transfected vectors were not significantly different (data not shown), suggesting that transfection efficiencies for the four vectors were similar.

Mouse, rat and human ODC $3^{\prime}$ UTR sequences all contain one canonical 5'-AUUUA-3' pentamer between bases 1857 and 1861 of the ODC transcript (Supplemental Figure 2, [17]). To determine if the presence of this pentamer influences HuR binding, we used biotinylated synthetic transcripts corresponding to our DEL02 construct containing either the wild-type AUUUA sequence, or a mutation of the

Biochemical Journal, Vol 442, No. 1 (February 2012): pg. 199-207. DOI. This article is (C Portland Press Limited and permission has been granted for this version to appear in e-Publications@Marquette. Portland Press Limited does not grant permission for this article to be further copied/distributed or hosted elsewhere without the express permission from Portland Press Limited. 
NOT THE PUBLISHED VERSION; this is the author's final, peer-reviewed manuscript. The published version may be accessed by following the link in the citation at the bottom of the page.

putative HuR binding site to GGGUA. The results show not only that HuR binds to the GGGUA-containing transcript, but it appears to associate more strongly when compared to the wild-type transcript (Figure 6B).

\section{DISCUSSION}

Previous experiments from our lab and others have demonstrated cap-dependent translational regulation of ODC in a fibroblast model. Our data reported here suggest that in response to Ras transformation of RIE-1 cells, rates of ODC translation initiation increase only slightly. However, ODC mRNA is markedly stabilized, and is available to be recruited onto polysomes, resulting in increased ODC synthesis. The clear increase in ODC mRNA stability observed is a potentially important component of the mechanism responsible for increasing ODC protein and activity in a variety of tumorigenic models. There are a number of reports in the literature demonstrating that both global mRNA stability and the stability of specific transcripts are functionally linked to translation, particularly during stress responses [29-32]. While the ODC transcript is much more stable in Ras12V cells compared to RIE-1 cells, the polysome distributions of endogenous ODC mRNA suggest that it is quite poorly translated in both cell lines, with most of the ODC mRNA present in early fractions corresponding to polysomes containing a small number of ribosomes. This supports the idea that increased mRNA stability in Ras12V cells plays an important role in the accumulation of ODC protein in these cells. Indeed, the 2-3 fold increase in transcription shown previously in Ras $12 \mathrm{~V}$ cells [6], coupled with the calculated 8-fold increase in RNA stability shown here, would potentially account for most of the 20-25fold increase in ODC enzyme activity that we have observed in RIE-1 cells transformed by Ras [6].

Although the mechanisms controlling mRNA decay are only beginning to be understood, treatment with rapamycin results in destabilization of several target RNAs in mouse embryo fibroblasts and breast cancer cell lines $[12,13]$, suggesting an alternative method of post- transcriptional control by mTORC1-dependent pathways. In agreement with this, our results show that inhibition of mTORC1 in Ras12V cells destabilizes ODC mRNA while only modestly changing translation initiation of the ODC transcript. Further, treatment of Ras12V cells with rapamycin reduces association of the stabilizing RBP

Biochemical Journal, Vol 442, No. 1 (February 2012): pg. 199-207. DOI. This article is (C Portland Press Limited and permission has been granted for this version to appear in e-Publications@Marquette. Portland Press Limited does not grant permission for this article to be further copied/distributed or hosted elsewhere without the express permission from Portland Press Limited. 
HuR with the ODC transcript. Taken together with our previous results, which show a functional link between HuR binding and ODC mRNA stability [17], these data suggest that activation of mTORC1 may help regulate ODC transcript decay by directing the association of this stabilizing factor with cis-acting elements within the ODC sequence.

Our data suggest that elements between base 1969 and base 2141 of the ODC sequence are necessary to stabilize the ODC transcript. This includes the sequence that we identified previously as containing multiple HuR binding sites [17]. In this context, it is interesting to note that in the in vitro assay used for these experiments HuR is capable of binding to the DEL02 deletion mutant, yet this transcript is significantly less stable than the full length ODC 3'UTR when transfected into Ras12V cells, suggesting that additional binding proteins are acting in concert or competition with HuR to control the decay of the ODC mRNA. This interpretation is supported by our results showing that endogenous HuR present in the RIE-1 cytoplasmic lysate does not interact with the ODC 3'UTR. Although previous results suggest that the sub-cellular localization of HuR responds to changes in activity of AMP-activated protein kinase, which is upstream of mTOR $[33,34]$, we see no change in HuR localization in rapamycin-treated Ras $12 \mathrm{~V}$ cells even though association of HuR with the ODC transcript is decreased. This further supports the idea of other trans factors competing with HuR for binding to the ODC message.

HuR binding to the ODC $3^{\prime}$ UTR is not abolished by mutation of the consensus ARE sequence $5^{\prime}$-AUUUA-3' to GGGUA, suggesting this is not an important site of interaction. While AUUUA is classically defined as a canonical ARE, other more heterogeneous AU- and U-rich sequences have also been shown to bind RBPs, including HuR [15], and consensus sequences controlling mRNA stability have not yet been strictly defined. It is also well known that the ODC 5'UTR has a profound affect on ODC translation [35-39], and a contribution of the 5'UTR to transcript stability cannot be ruled out from these experiments. However, the RNA half-life of our 3'UTR full-length reporter plasmid is quite similar to the half-life of the endogenous ODC transcript in both cell lines.

Neither the increased stability of ODC RNA and its recruitment into polysomes in Ras $12 \mathrm{~V}$ cells, nor the destabilization of the ODC 
message in the presence of rapamycin, are fully reflected in the total RNA levels. One hypothesis to explain these observations is that in RIE-1 cells much of the ODC RNA is stored in cytoplasmic P-bodies, aggregates of translationally repressed mRNA that are associated with decapping and deadenylation machinery. Upon activation of Rasdependent pathways, ODC RNA is released from these bodies to be recruited into polysomes in an $\mathrm{mTOR}$-dependent manner. This notion is plausible, as it has been shown that P-bodies are dynamic foci that are able to assemble and disassemble based upon changes in cellular conditions [40]. Other studies have suggested that HuR may interact with miRNAs through an interdependent mechanism that causes release of specific transcripts from P-bodies and their entry onto polysomes in response to various types of cellular stresses [41]. Although application of a genome-wide target prediction algorithm [42] predicts that several miRNAs may interact with the ODC 3'UTR with favorable energies, a role for miRNAs in ODC post-transcriptional regulation has not been defined.

In conclusion, we have demonstrated that, analogous to other growth regulatory proteins such as Cyclin D1, VEGF and c-Myc, the synthesis of ODC can be regulated at the levels of both mRNA translation and mRNA stability [23,43-45]. Changes in ODC mRNA stability are at least partly dependent on the activity of mTORC1, which we show for the first time can not only regulate initiation of ODC translation but can also control ODC mRNA decay. Binding of the stabilizing RBP HuR to the ODC transcript is reduced when mTORC1 is inhibited, suggesting that mTOR-dependent pathways regulate this association, and possibly that of additional RBPs. Thus, these experiments extend our previous findings [17] to further define the mechanism by which ODC synthesis is controlled, and identify additional targets that influence intracellular ODC activity. 
NOT THE PUBLISHED VERSION; this is the author's final, peer-reviewed manuscript. The published version may be accessed by following the link in the citation at the bottom of the page.

\title{
Supplementary Material
}

\author{
Supplemental figure 1
}

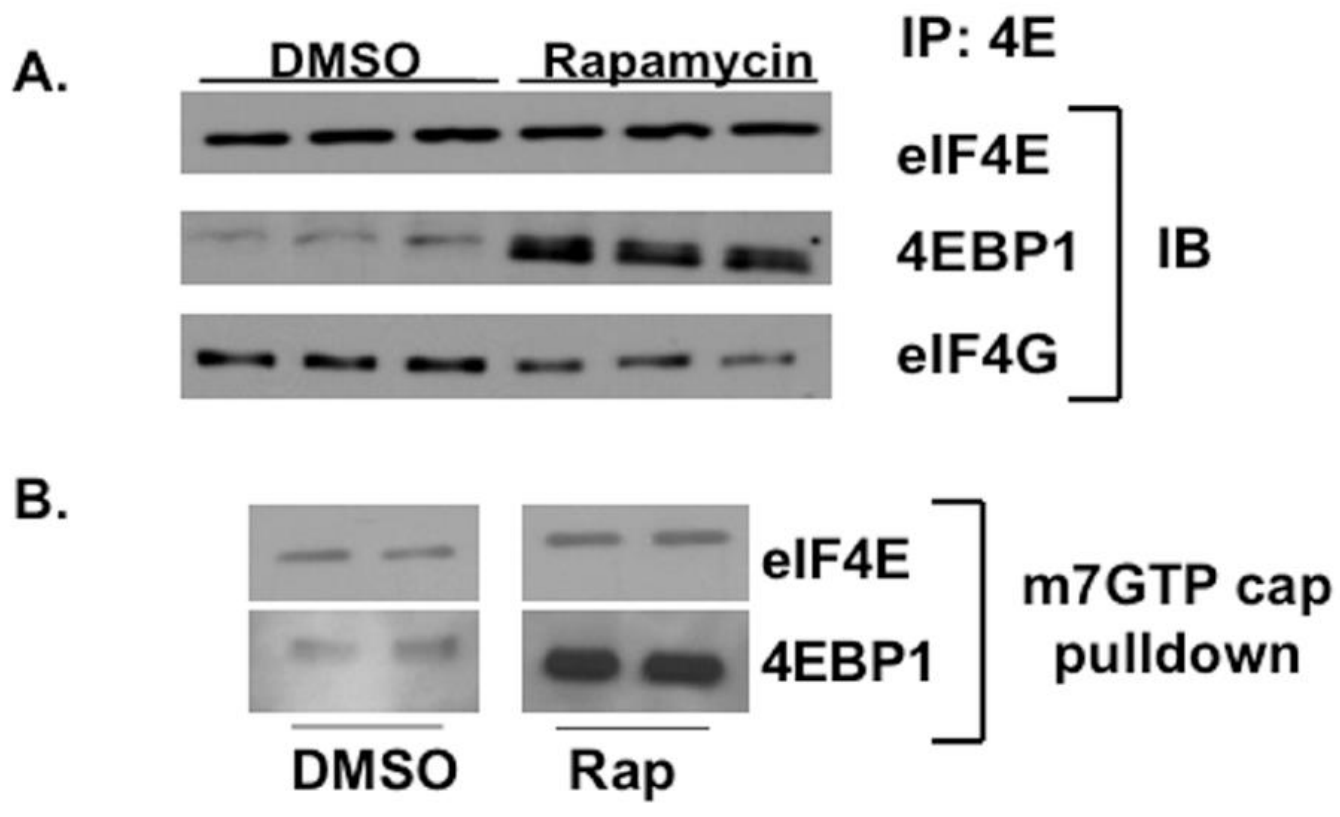

Biochemical Journal, Vol 442, No. 1 (February 2012): pg. 199-207. DOI. This article is (C Portland Press Limited and permission has been granted for this version to appear in e-Publications@Marquette. Portland Press Limited does not grant permission for this article to be further copied/distributed or hosted elsewhere without the express permission from Portland Press Limited. 
NOT THE PUBLISHED VERSION; this is the author's final, peer-reviewed manuscript. The published version may be accessed by following the link in the citation at the bottom of the page.

\section{Supplemental figure 2}

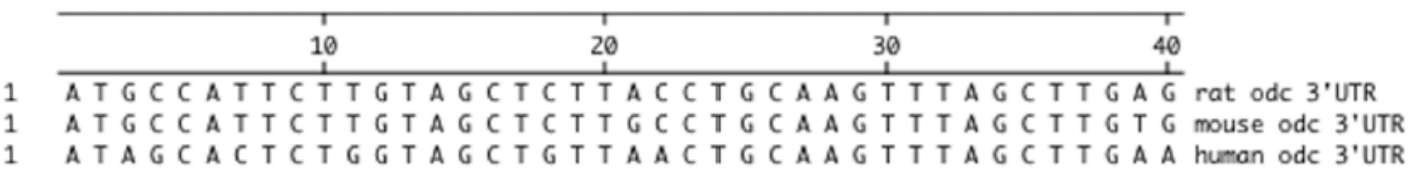

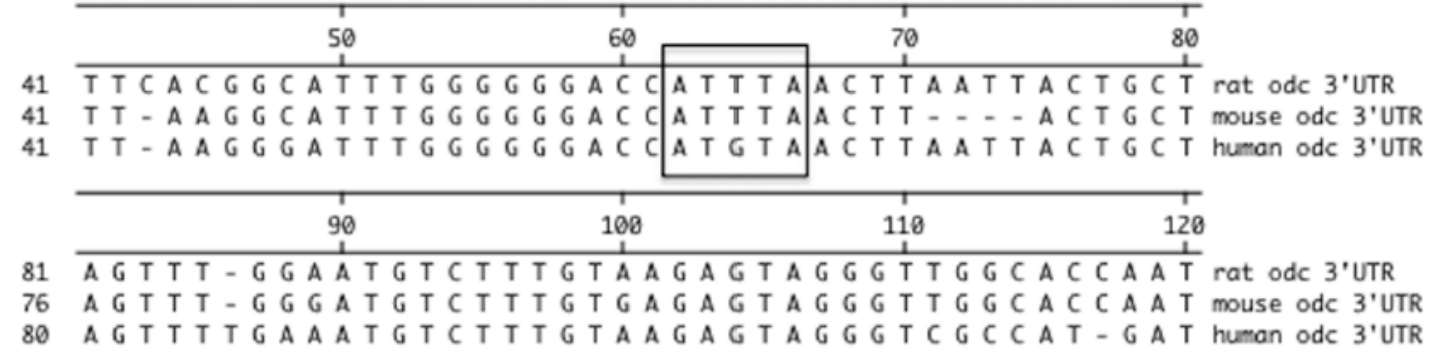

\begin{tabular}{cccc}
\hline 130 & 140 & 150 & 160 \\
\hline 120 & 1 & 1 \\
\hline
\end{tabular}

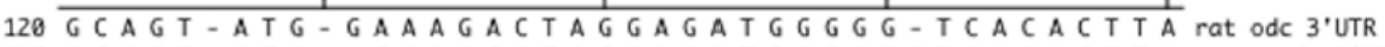
115 G C A G T - A T G - - G A A G G C T A G G A G A T G G G G G G T C A C A C T T A mouse odc 3'UTR 119 G C A G C C A T A T G G A A G A C T A G G A T A T G G G . - T C A C A C T T A human odc 3' UTR

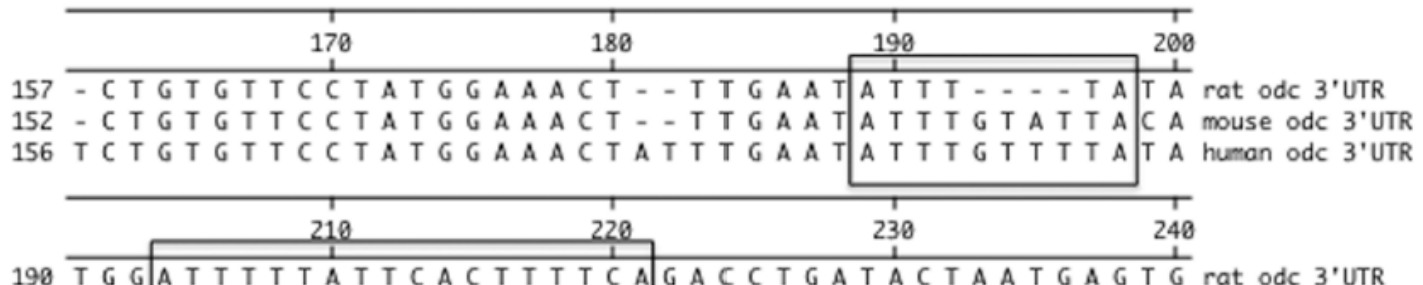
189 T G G A T T T T T A T T C A C T T T T C A G A C A T G A T A C T A A C G T G T G mouse odc 3'UTR 196 T G G A T T T T T A T T C A C T C T T C A G A C A C G C T A C T C A A G A G T G human odc 3'UTR

\begin{tabular}{cccc}
\hline 1 & 1 \\
250 & 260 & 270 & 280 \\
\hline
\end{tabular}

230 C C C CTCGGCTGCTGAGCA A G CATTTGTAGCTTGTACATTG rat odc 3'UTR 229 C C C C T C A G C T G C T G A G C A A G C G T T T G T A G C T T G T A C A T T G mouse odc 3'UTR 236 C C C C T C A G C T G C T G A A C A A G C A T T T G T A G C T T G T A C A A T G human odc 3' UTR

\section{Supplemental figure legend}

\section{Supplemental Figure 1.}

Rapamycin treatment inhibits cap complex formation in Ras12V cells. Plates grown in parallel with those shown in Figure 2A were harvested and subjected to either IP analysis or M7GTP sepharose chromatography. (A) Using IP of total eIF4E, the amount of 4EBP1 or eIF4G associated with eIF4E was determined by Western blot analysis. IP analysis using mouse IgG served as a negative control. (B) M7GTP sepharose chromatography was performed and the amount of eIF4E or 4EBP1 associated with the m7GTP cap was analyzed by immunoprecipitation.

Biochemical Journal, Vol 442, No. 1 (February 2012): pg. 199-207. DOI. This article is @ Portland Press Limited and permission has been granted for this version to appear in e-Publications@Marquette. Portland Press Limited does not grant permission for this article to be further copied/distributed or hosted elsewhere without the express permission from Portland Press Limited. 


\section{Supplemental Figure 2.}

Alignment of the proximal mouse, rat and human ODC 3'UTRs. Potential AREs, either 5'-AUUUA-3' pentamers or extended AU-rich regions, are shown in boxes.

\section{Acknowledgments}

The authors would like to thank Dr. Scot R. Kimball, Penn State College of Medicine, for help with the polysome profiles. The authors have no competing financial interest in relation to any of the work described.

FUNDING: This work was funded by an Inflammatory Bowel Disease Research Facilitation Award, Dept. of Colorectal Surgery, Penn State College of Medicine (LMS), and the National Institutes of Health [CA82768 and CA142051 to LMS; DK57819 to JYW].

\section{Abbreviations used}

$\begin{array}{ll}\text { ARE } & \text { adenylate- and uridylate-rich element } \\ \text { EEF1A } & \text { eukaryotic elongation factor 1A } \\ \text { eIF4E } & \text { eukaryotic initiation factor 4E } \\ \text { ERK } & \text { extracellular signal-regulated kinase } \\ \text { MEK } & \text { mitogen-activated protein kinase kinase } \\ \text { miRNA } & \text { microRNA } \\ \text { RNP IP } & \text { ribonucleoprotein immunoprecipitation } \\ \text { mTOR } & \text { mammalian target of Rapamycin } \\ \text { ODC } & \text { ornithine decarboxylase } \\ \text { P-body } & \text { processing body } \\ \text { PI3K } & \text { phosphoinositide 3-kinase } \\ \text { RBP } & \text { RNA binding protein } \\ \text { SiRNA } & \text { small interfering RNA } \\ \text { UTR } & \text { untranslated region }\end{array}$

\section{References}

1. Gerner EW, Meyskens FL Jr. Polyamines and cancer: old molecules, new understanding. Nat Rev Cancer. 2004; 4:781-792.

2. Shantz LM, Pegg AE. Overproduction of ornithine decarboxylase caused by relief of translational repression is associated with neoplastic transformation. Cancer Res. 1994; 54:2313-2316.

Biochemical Journal, Vol 442, No. 1 (February 2012): pg. 199-207. DOI. This article is (C Portland Press Limited and permission has been granted for this version to appear in e-Publications@Marquette. Portland Press Limited does not grant permission for this article to be further copied/distributed or hosted elsewhere without the express permission from Portland Press Limited. 
NOT THE PUBLISHED VERSION; this is the author's final, peer-reviewed manuscript. The published version may be accessed by following the link in the citation at the bottom of the page.

3. Shantz LM. Transcriptional and translational control of ornithine decarboxylase during Ras transformation. Biochem J. 2004; 377:257264.

4. Feith DJ, Bol DK, Carboni J, Lynch M, Sass-Kuhn S, Shoop P, Shantz LM. Induction of ornithine decarboxylase activity is a necessary step for MEK-induced skin tumorigenesis. Cancer Res. 2005; 65:572-578.

5. Feith DJ, Origanti S, Shoop PL, Sass-Kuhn S, Shantz LM. Tumor suppressor activity of ODC antizyme in MEK-driven skin tumorigenesis. Carcinogenesis. 2006; 27:1090-1098.

6. Origanti S, Shantz LM. Ras transformation of RIE-1 cells activates capindependent translation of ornithine decarboxylase: regulation by the Raf/MEK/ERK and phosphatidylinositol 3-kinase pathways. Cancer Res. 2007; 67:4834-4842.

7. Repasky GA, Chenette EJ, Der CJ. Renewing the conspiracy theory debate: does Raf function alone to mediate Ras oncogenesis? Trends Cell Biol. 2004; 14:639-647.

8. Rousseau D, Kaspar R, Rosenwald I, Gehrke L, Sonenberg N. Translation initiation of ornithine decarboxylase and nucleocytoplasmic transport of cyclin D1 mRNA are increased in cells overexpressing eukaryotic initiation factor 4E. Proc Natl Acad Sci USA. 1996; 93:1065-1070.

9. Proud CG. Signalling to translation: how signal transduction pathways control the protein synthetic machinery. Biochem J. 2007; 403:217234.

10. Albig $A R$, Decker $C J$. The target of rapamycin signaling pathway regulates mRNA turnover in the yeast Saccharomyces cerevisiae. Mol Biol Cell. $2001 ; 12: 3428-3438$.

11. Foat BC, Houshmandi SS, Olivas WM, Bussemaker HJ. Profiling conditionspecific, genome-wide regulation of mRNA stability in yeast. Proc Natl Acad Sci U S A. 2005; 102:17675-17680.

12. Marderosian M, Sharma A, Funk AP, Vartanian R, Masri J, Jo OD, Gera JF. Tristetraprolin regulates Cyclin D1 and c-Myc mRNA stability in response to rapamycin in an Akt-dependent manner via p38 MAPK signaling. Oncogene. 2006; 25:6277-6290.

13. Suswam EA, Nabors LB, Huang Y, Yang X, King PH. IL-1beta induces stabilization of IL-8 mRNA in malignant breast cancer cells via the $3^{\prime}$ untranslated region: Involvement of divergent RNA-binding factors HuR, KSRP and TIAR. Int J Cancer. 2005; 113:911-919.

Biochemical Journal, Vol 442, No. 1 (February 2012): pg. 199-207. DOI. This article is (C) Portland Press Limited and permission has been granted for this version to appear in e-Publications@Marquette. Portland Press Limited does not grant permission for this article to be further copied/distributed or hosted elsewhere without the express permission from Portland Press Limited. 
NOT THE PUBLISHED VERSION; this is the author's final, peer-reviewed manuscript. The published version may be accessed by following the link in the citation at the bottom of the page.

14. Garneau NL, Wilusz J, Wilusz CJ. The highways and byways of mRNA decay. Nat Rev Mol Cell Biol. 2007; 8:113-126.

15. Barreau C, Paillard L, Osborne HB. AU-rich elements and associated factors: are there unifying principles? Nucleic Acids Res. 2005; 33:7138-7150.

16. Eulalio A, Behm-Ansmant I, Izaurralde E. P bodies: at the crossroads of post-transcriptional pathways. Nat Rev Mol Cell Biol. 2007; 8:9-22.

17. Nowotarski SL, Shantz LM. Cytoplasmic accumulation of the RNA-binding protein HuR stabilizes the ornithine decarboxylase transcript in a murine nonmelanoma skin cancer model. J Biol Chem. 2010; 285:31885-31894.

18. Svitkin YV, Pause A, Haghighat A, Pyronnet S, Witherell G, Belsham GJ, Sonenberg $N$. The requirement for eukaryotic initiation factor 4A (eIF$4 \mathrm{~A}$ ) in translation is in direct proportion to the degree of mRNA $5^{\prime}$ secondary structure. RNA. 2001; 7:382-394.

19. Johannes G, Sarnow P. Cap-independent polysomal association of natural mRNAs encoding c- myc, BiP, and eIF4G conferred by internal ribosome entry sites. Rna. 1998; 4:1500-1513.

20. Song K, Wang H, Krebs TL, Danielpour D. Novel roles of Akt and mTOR in suppressing TGF- beta/ALK5-mediated Smad3 activation. Embo J. 2006; 25:58-69.

21. Mazan-Mamczarz K, Galban S, Lopez de Silanes I, Martindale JL, Atasoy $\mathrm{U}$, Keene JD, Gorospe M. RNA-binding protein HuR enhances p53 translation in response to ultraviolet light irradiation. Proc Natl Acad Sci U S A. 2003; 100:8354-8359.

22. Zou T, Mazan-Mamczarz K, Rao JN, Liu L, Marasa BS, Zhang AH, Xiao L, Pullmann R, Gorospe M, Wang JY. Polyamine depletion increases cytoplasmic levels of RNA-binding protein HuR leading to stabilization of nucleophosmin and p53 mRNAs. J Biol Chem. 2006; 281:1938719394.

23. Lal A, Mazan-Mamczarz K, Kawai T, Yang X, Martindale JL, Gorospe M. Concurrent versus individual binding of HuR and AUF1 to common labile target mRNAs. EMBO J. 2004; 23:3092- 3102.

24. Rao JN, Liu L, Zou T, Marasa BS, Boneva D, Wang SR, Malone DL, Turner DJ, Wang JY. Polyamines are required for phospholipase $\mathrm{C}_{Y} 1$ expression promoting intestinal epithelial reconstitution after wounding. Am J Physiol Gastrointest Liver Physiol. 2006; 292:335343.

Biochemical Journal, Vol 442, No. 1 (February 2012): pg. 199-207. DOI. This article is (C Portland Press Limited and permission has been granted for this version to appear in e-Publications@Marquette. Portland Press Limited does not grant permission for this article to be further copied/distributed or hosted elsewhere without the express permission from Portland Press Limited. 
NOT THE PUBLISHED VERSION; this is the author's final, peer-reviewed manuscript. The published version may be accessed by following the link in the citation at the bottom of the page.

25. Liu L, Guo X, Rao JN, Zou T, Marasa BS, Chen J, Greenspon J, Casero RA Jr, Wang JY. Polyamine-modulated c-Myc expression in normal intestinal epithelial cells regulates p21Cip1 transcription through a proximal promoter region. Biochem J. 2006; 398:257-267.

26. Carracedo A, Ma L, Teruya-Feldstein J, Rojo F, Salmena L, Alimonti A, Egia A, Sasaki AT, Thomas G, Kozma SC, Papa A, Nardella C, Cantley LC, Baselga J, Pandolfi PP. Inhibition of mTORC1 leads to MAPK pathway activation through a PI3K-dependent feedback loop in human cancer. J Clin Invest. 2008; 118:3065-3074.

27. Sarbassov DD, Ali SM, Kim DH, Guertin DA, Latek RR, ErdjumentBromage $H$, Tempst $P$, Sabatini DM. Rictor, a novel binding partner of mTOR, defines a rapamycin-insensitive and raptor-independent pathway that regulates the cytoskeleton. Curr Biol. 2004; 14:12961302.

28. Jacinto $E$, Loewith $R$, Schmidt A, Lin S, Ruegg MA, Hall A, Hall MN. Mammalian TOR complex 2 controls the actin cytoskeleton and is rapamycin insensitive. Nat Cell Biol. 2004; 6:1122-1128.

29. Kawai T, Fan J, Mazan-Mamczarz K, Gorospe M. Global mRNA stabilization preferentially linked to translational repression during the endoplasmic reticulum stress response. Mol Cell Biol. 2004; 24:67736787.

30. Tong $X$, Van Dross RT, Abu-Yousif A, Morrison AR, Pelling JC. Apigenin prevents UVB- Induced cyclooxygenase 2 expression: Coupled mRNA stabilization and translational inhibition. Mol Cell Biol. 2007; 27:283296.

31. Katsanou V, Papadaki O, Milatos S, Blackshear PJ, Anderson P, Kollias G, Kontoyiannis DL. HuR as a negative posttranscriptional modulator in inflammation. Mol Cell. 2005; 19:777-789.

32. Kawai T, Lal A, Yang X, Galban S, Mazan-Mamczarz K, Gorospe M. Translational control of cytochrome $c$ by RNA-binding proteins TIA-1 and HuR. Mol Cell Biol. 2006; 26:3295-3307.

33. Zou T, Liu L, Rao JN, Marasa BS, Chen J, Xiao L, Zhou H, Gorospe M, Wang JY. Polyamines modulate the subcellular localization of RNAbinding protein HuR through AMP-activated protein kinase-regulated phosphorylation and acetylation of importin alpha1. Biochem J. 2008; 409:389- 398.

Biochemical Journal, Vol 442, No. 1 (February 2012): pg. 199-207. DOI. This article is (C) Portland Press Limited and permission has been granted for this version to appear in e-Publications@Marquette. Portland Press Limited does not grant permission for this article to be further copied/distributed or hosted elsewhere without the express permission from Portland Press Limited. 
34. Zhang J, Bowden GT. UVB irradiation regulates COX-2 mRNA stability through AMPK and HuR in human keratinocytes. Molecular Carcinogenesis. 2008; 47:974-983.

35. Ito K, Kashiwagi K, Watanabe S, Kameji T, Hayashi S, Igarashi K. Influence of the $5^{\prime}$ - untranslated region of ornithine decarboxylase mRNA and spermidine on ornithine decarboxylase synthesis. J Biol Chem. 1990; 265:13036-13041.

36. Kashiwagi $\mathrm{K}$, Ito $\mathrm{K}$, Igarashi $\mathrm{K}$. Spermidine regulation of ornithine decarboxylase synthesis by a GC-rich sequence of the $5^{\prime}$-untranslated region. Biochem Biophys Res Comm. 1991; 178:815-822.

37. Manzella JM, Blackshear PJ. Specific protein binding to a conserved region of the ornithine decarboxylase mRNA $5^{\prime}$-untranslated region. J Biol Chem. 1992; 267:7077-7082.

38. Grens A, Scheffler IE. The 5'- and $3^{\prime}$-untranslated regions of ornithine decarboxylase mRNA affect the translational efficiency. J Biol Chem. 1990; 265:11810-11816.

39. Lorenzini EC, Scheffler IE. Co-operation of the $5^{\prime}$ and $3^{\prime}$ untranslated regions of ornithine decarboxylase mRNA and inhibitory role of its $3^{\prime}$ untranslated region in regulating the translational efficiency of hybrid RNA species via cellular factors. Biochem J. 1997; 326:361-367.

40. Kedersha N, Stoecklin G, Ayodele M, Yacono P, Lykke-Andersen J, Fritzler MJ, Scheuner D, Kaufman RJ, Golan DE, Anderson P. Stress granules and processing bodies are dynamically linked sites of mRNP remodeling. J Cell Biol. 2005; 169:871-884.

41. Bhattacharyya SN, Habermacher R, Martine U, Closs EI, Filipowicz W. Relief of microRNA- mediated translational repression in human cells subjected to stress. Cell. 2006; 125:1111-1124. [PubMed: 16777601]

42. Kertesz M, Iovino N, Unnerstall U, Gaul U, Segal E. The role of site accessibility in microRNA target recognition. Nat Genet. 2007; 39: $1278-1284$.

43. Liao $B$, Hu Y, Brewer G. Competitive binding of AUF1 and TIAR to MYC mRNA controls its translation. Nat Struct Mol Biol. 2007; 14:511-518.

44. Lai WS, Parker JS, Grissom SF, Stumpo DJ, Blackshear PJ. Novel mRNA targets for tristetraprolin (TTP) identified by global analysis of stabilized transcripts in TTP-deficient fibroblasts. Mol Cell Biol. 2006; 26:9196-9208.

Biochemical Journal, Vol 442, No. 1 (February 2012): pg. 199-207. DOI. This article is (C) Portland Press Limited and permission has been granted for this version to appear in e-Publications@Marquette. Portland Press Limited does not grant permission for this article to be further copied/distributed or hosted elsewhere without the express permission from Portland Press Limited. 
NOT THE PUBLISHED VERSION; this is the author's final, peer-reviewed manuscript. The published version may be accessed by following the link in the citation at the bottom of the page.

45. Topisirovic I, Siddiqui N, Orolicki S, Skrabanek LA, Tremblay M, Hoang T, Borden KL. Stability of eukaryotic translation initiation factor 4E mRNA is regulated by HuR, and this activity is dysregulated in cancer. Mol Cell Biol. 2009; 29:1152-1162.
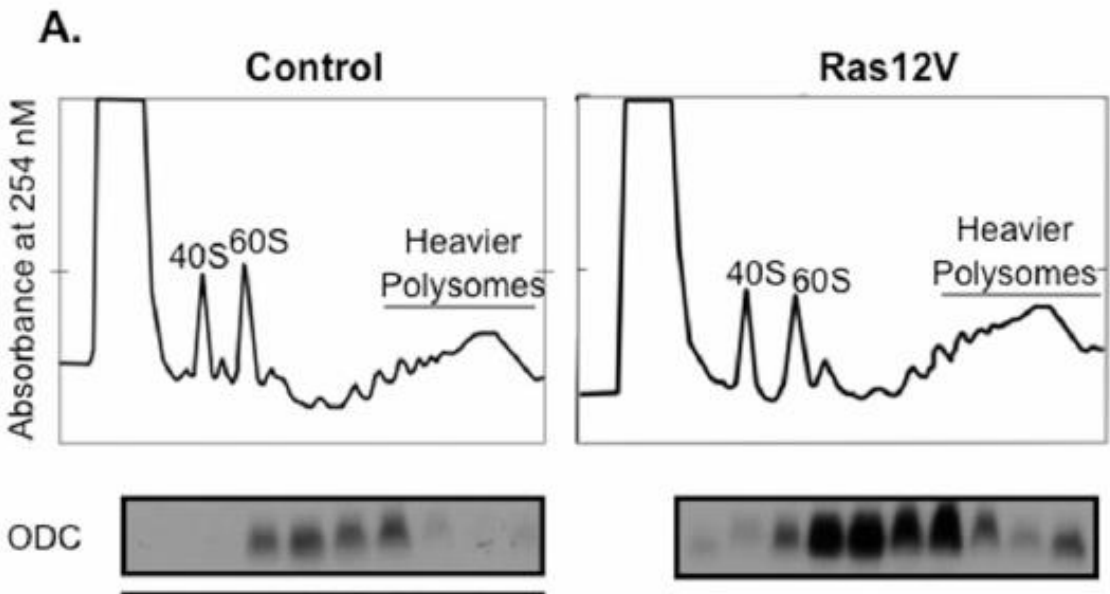

Cyclo
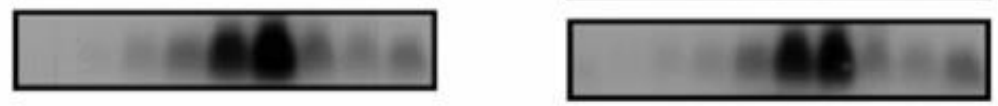

B.
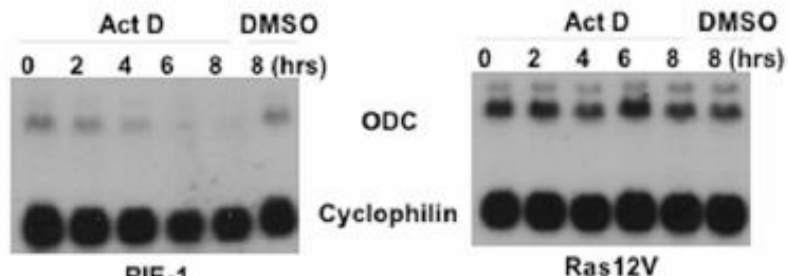

RIE-1

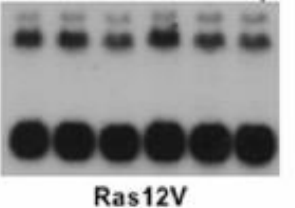

C.

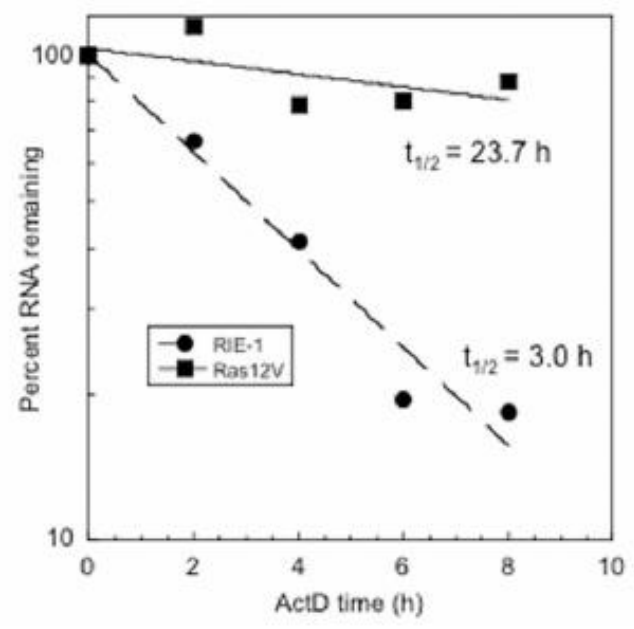

\section{Figure 1. Analysis of ODC RNA translation and stability}

Biochemical Journal, Vol 442, No. 1 (February 2012): pg. 199-207. DOI. This article is (C Portland Press Limited and permission has been granted for this version to appear in e-Publications@Marquette. Portland Press Limited does not grant permission for this article to be further copied/distributed or hosted elsewhere without the express permission from Portland Press Limited. 
(A) Polysomal analysis of ODC RNA was carried out in both RIE-1 and Ras $12 \mathrm{~V}$ cells as described in the Experimental section. Equal volumes of RNA were loaded per lane and Northern blots were probed with radiolabeled CDNA complementary to full length ODC, then stripped and reprobed with cDNA complementary to cyclophilin (Cyclo). The experiment was performed in duplicate with reproducible results. (B) To measure RNA stability, cells were treated with either $5 \mu \mathrm{g} / \mathrm{ml}$ Actinomycin $D$ (Act D) or DMSO vehicle. RNA was isolated immediately after addition of Act $D$ at $0 \mathrm{~h}$ and thereafter at $2,4,6$ and $8 \mathrm{~h}$ and at $8 \mathrm{~h}$ for DMSO-treated cells. For Northern analysis, $20 \mu \mathrm{g}$ of total RNA was loaded per lane and probed for ODC and cyclophilin simultaneously. The experiment was performed in duplicate with reproducible results. (C) Quantitation of the results presented in (B). The absolute values for absorbance corresponding to time $=0$ were 5.21 for Ras $12 \mathrm{~V}$ cells and 2.10 for RIE- 1 cells (arbitrary units).

B.

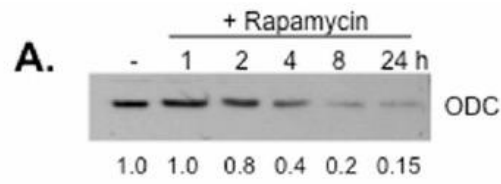

A.

B.

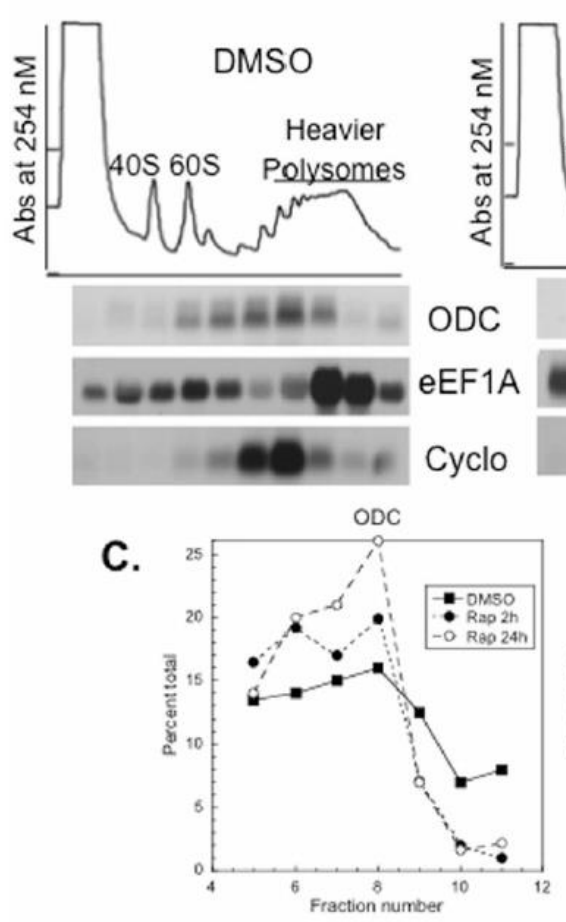

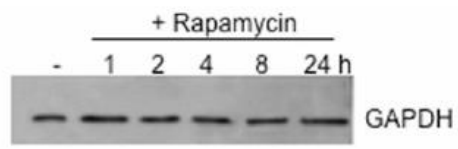

GAPDH

\section{Figure 2. Effect of mTOR inhibition on ODC translation initiation and protein levels in Ras12V cells}

(A) Cells were treated with either DMSO or $100 \mathrm{nM}$ rapamycin (Rap) for the times indicated and harvested for Western blots of ODC protein as described in the Experimental section. Quantitation of bands was performed by densitometry and expressed as a fraction of the band corresponding to untreated cells $(-)$. GAPDH 
NOT THE PUBLISHED VERSION; this is the author's final, peer-reviewed manuscript. The published version may be accessed by following the link in the citation at the bottom of the page.

served as a control. (B) Cells were treated with either DMSO or $100 \mathrm{nM}$ rapamycin for the times indicated and polysome analysis was carried out as described in the Experimental section. Northern blots were simultaneously probed for ODC and Cyclophilin, then were stripped and reprobed for eEF1A. The experiment was performed in duplicate with reproducible results. (C) Quantitation of the polysome profiles shown in (B).

A.
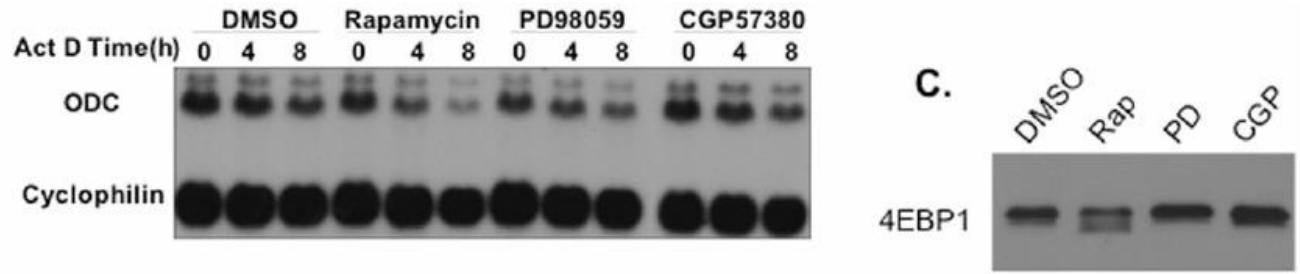

B.
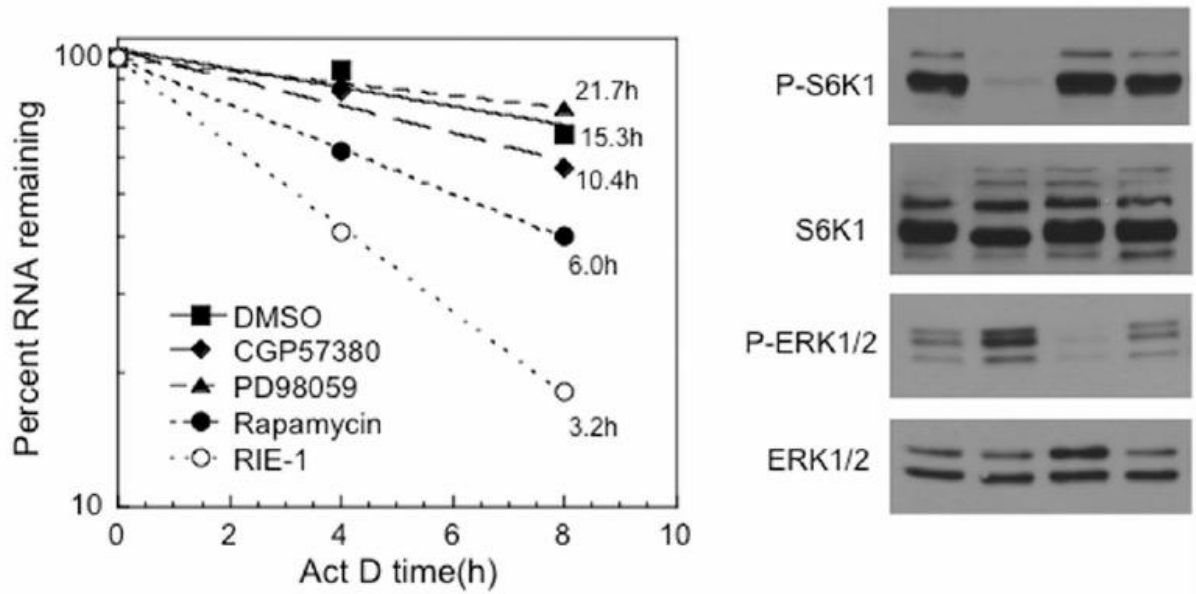

\section{Figure 3. Effect of Ras downstream signaling inhibition on ODC mRNA decay}

(A) Stability of ODC RNA was analyzed as described in Figure 1, except $100 \mathrm{nM}$ rapamycin, $50 \mu \mathrm{M}$ PD98059, $20 \mu \mathrm{M}$ CG57380 or vehicle DMSO were added $24 \mathrm{~h}$ before the addition of Actinomycin D (ActD). RNA was collected immediately after addition of ActD at $0 \mathrm{~h}$, and $4 \mathrm{~h}$ and $8 \mathrm{~h}$ later. (B) Quantitation of the results in (A). The absolute values for absorbance corresponding to time $=0$ were as follows: $\mathrm{DMSO}=2.11$;

Rapamycin =1.84; PD98059=1.49; CGP57380 $=2.00$ (arbitrary units). (C) Cells were treated with inhibitors at the concentrations described in $(A)$, harvested after $24 \mathrm{~h}$ in RIPA buffer, and analyzed for 4EBP1 and P-S6K1 as a measure of mTORC1 activity and P-ERK1/2 as a measure of MEK activity. P-S6K1 and P-ERK1/2 blots were then stripped and re-probed for total protein. All experiments were performed in duplicate or triplicate with reproducible results.

Biochemical Journal, Vol 442, No. 1 (February 2012): pg. 199-207. DOI. This article is @ Portland Press Limited and permission has been granted for this version to appear in e-Publications@Marquette. Portland Press Limited does not grant permission for this article to be further copied/distributed or hosted elsewhere without the express permission from Portland Press Limited. 
NOT THE PUBLISHED VERSION; this is the author's final, peer-reviewed manuscript. The published version may be accessed by following the link in the citation at the bottom of the page.

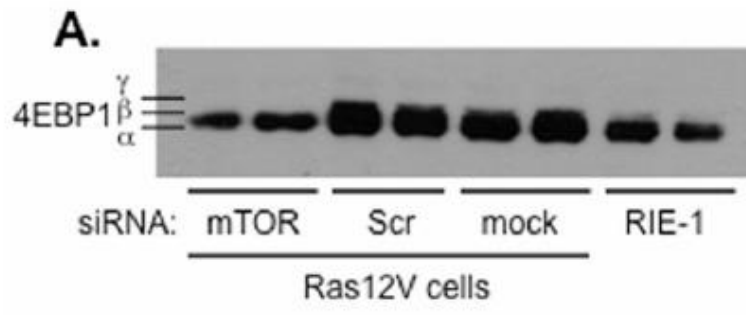

B.

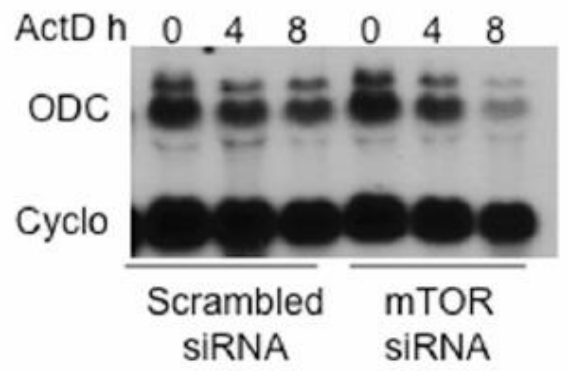

C.

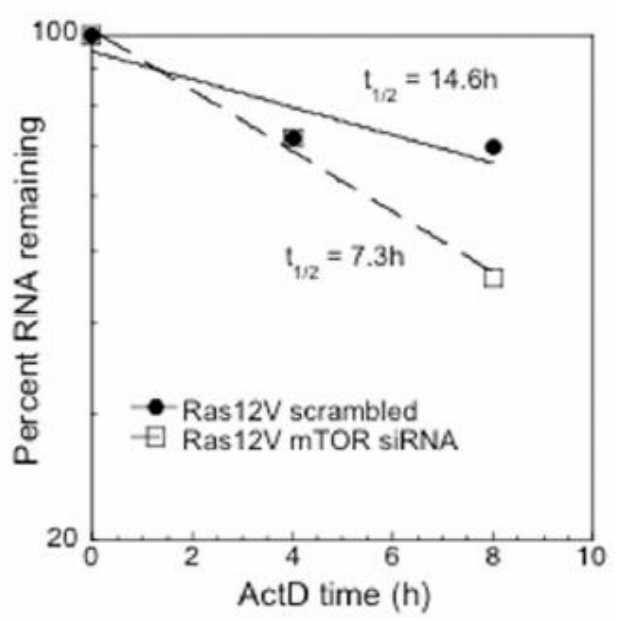

Figure 4. Regulation of ODC RNA stability by mTOR-dependent pathways

(A) Knockdown of mTOR with siRNA was performed as described in the Experimental section. Extent of mTORC1 knockdown was assessed by measuring the levels of hyperphosphorylated 4EBP1 using Western blot analysis and comparing to parental RIE-1 cells. (B) ODC mRNA stability in the presence of siRNA directed against mTOR or a scrambled control siRNA was measured by Northern blot analysis.

(C) Quantitation of the results in (B). All experiments were performed in duplicate with reproducible results.

Biochemical Journal, Vol 442, No. 1 (February 2012): pg. 199-207. DOI. This article is (C Portland Press Limited and permission has been granted for this version to appear in e-Publications@Marquette. Portland Press Limited does not grant permission for this article to be further copied/distributed or hosted elsewhere without the express permission from Portland Press Limited. 
A. Cytoplasmic proteins

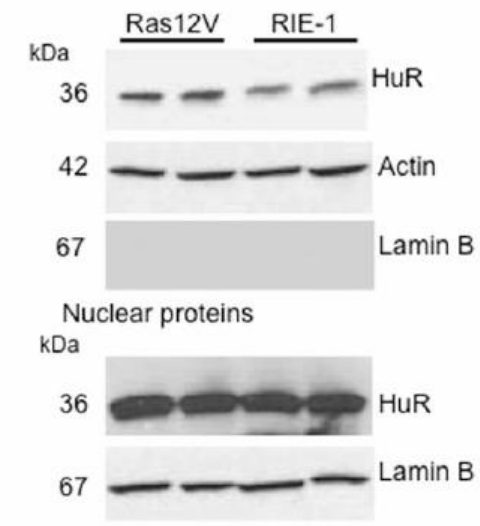

C.

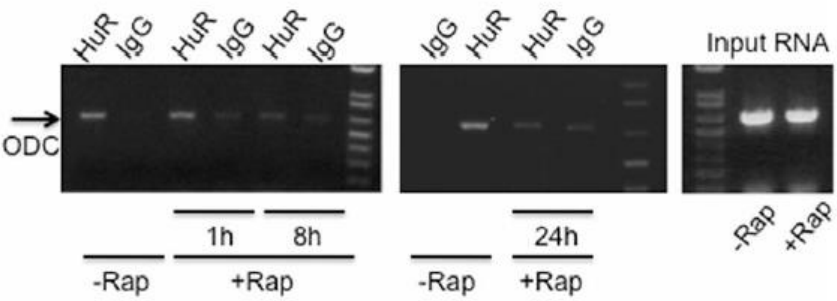

D.

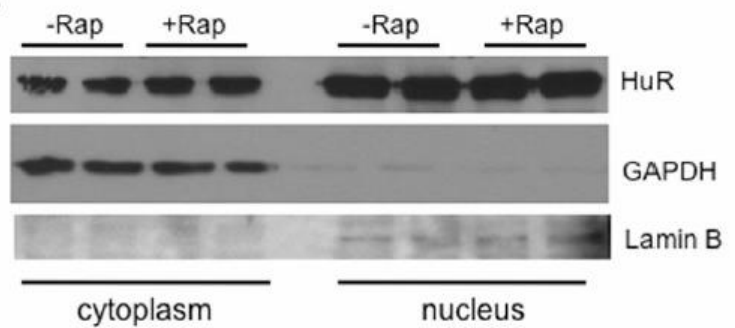

Figure 5. The mRNA binding protein HuR associates with the ODC transcript in Ras12V cells in a rapamycin-dependent manner

(A) RIE-1 and Ras12V cells were fractionated into cytoplasmic and nuclear extracts and HuR localization was detected by Western blot analysis. Actin was used as a cytoplasmic marker and Lamin B was used as a nuclear marker. Band quantitation estimated a 2-fold increase in cytoplasmic HuR in Ras12V cells. (B) Cytoplasmic lysates from Ras12V and RIE-1 cells were used for RNP IP analysis with anti-HuR or nonspecific mouse IgG. RNA in the IP material was extracted with phenol-chloroform, used in a PCR reaction, and visualized on a $2 \%$ agarose gel. The levels of ODC mRNA were assessed by PCR using primers specific for the coding region. The same primers were used to estimate the amount of input RNA using CDNA derived from each cell line as a template. The experiment was conducted in triplicate with reproducible results. (C) The RNP IP experiment described in was repeated using Ras $12 \mathrm{~V}$ cells that had been pre-treated for $1 \mathrm{~h}, 8 \mathrm{~h}$, or $24 \mathrm{~h}$ with $100 \mathrm{nM}$ rapamycin or with DMSO vehicle for $24 \mathrm{~h}$. Input RNA was assayed in cells treated with rapamycin or DMSO for $24 \mathrm{~h}$. The experiment was conducted in triplicate with reproducible results. (D) Nuclear/cytoplasmic fractionation was performed as described in (A) using Ras $12 \mathrm{~V}$ cells treated with rapamycin or DMSO vehicle for $24 \mathrm{~h}$. GAPDH served as cytoplasmic marker and Lamin B served as nuclear marker. 
A.

Deletion constructs

Full 3' UTR

DEL01

DEL02

DEL03

B.

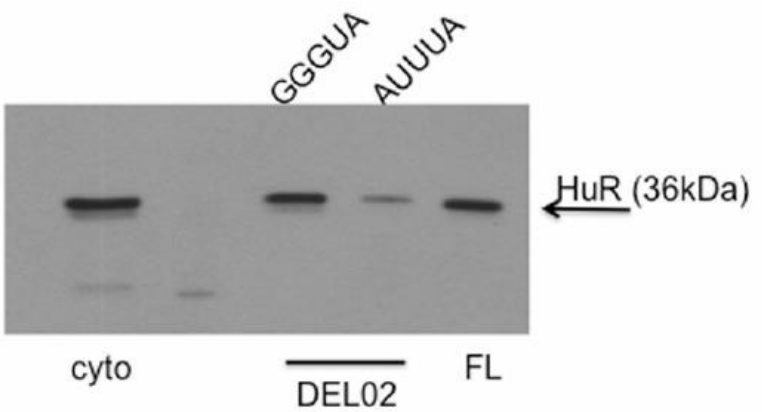

RNA half-life (hours \pm SEM) Ras $12 \mathrm{~V}$ cells

RIE-1 cells

$22.3 \pm 5.9$

$9.2 ; 5.7$

$27.1 \pm 6.3$

$9.9 \pm 2.2$

$5.3 ; 7.8$

\section{Figure 6. The ODC 3'UTR contains a cis-acting RNA stability element}

(A) Cells were grown for $48 \mathrm{~h}$ then transfected with luciferase expression plasmids containing either the full length ODC 3'UTR or one of three 3'UTR deletion constructs, as shown in the schematic representation. RNA half-life was measured $48 \mathrm{~h}$ later as described in Figure 1. Results are from 2-5 independent experiments. Where two experiments were performed, results from both experiments are shown, others are the means \pm SEM. (B) Ras $12 \mathrm{~V}$ cytoplasmic lysate $(120 \mu \mathrm{g})$ was incubated with $15 \mu \mathrm{l}$ of biotin-labeled synthetic probes corresponding to the DEL02 sequence containing either the wild-type (AUUUA) or mutated (GGGUA) ARE and Western blot for HuR was performed. The full length 3'UTR (FL) was used as a positive control. Cytoplasmic lysate (cyto) is also shown. This experiment was done in duplicate with similar results.

Biochemical Journal, Vol 442, No. 1 (February 2012): pg. 199-207. DOI. This article is (C Portland Press Limited and permission has been granted for this version to appear in e-Publications@Marquette. Portland Press Limited does not grant permission for this article to be further copied/distributed or hosted elsewhere without the express permission from Portland Press Limited. 